\title{
Manajemen Praktek Kerja Lapangan Menggunakan Metode RAD Dan Pengujian SUS Pada Instansi SMK dan CV
}

\author{
Arif hadi Sumitro*1, M. Taufiq ${ }^{2}$ \\ ${ }^{1,2}$ Sekolah Tinggi Ilmu Komputer PGRI Banyuwangi; Jl. Jenderal Ahmad Yani No.80, Taman Baru, Kec. \\ Banyuwangi, Kabupaten Banyuwangi, Jawa Timur 68416 \\ Program Studi Teknik Informatika \\ ${ }^{* 1}$ Radenarifhadisumitro@ gmail.com, ${ }^{2}$ mtaufiq39@gmail.com
}

\begin{abstract}
Abstrak - Praktek Kerja Lapangan (PKL) diberikan untuk siswa sekolah menengah kejuruan yang sudah memasuki kelas 2 atau kelas XI SMK. Tujuan PKL adalah untuk memberikan kemampuan dan pengalaman bagi siswa untuk mengimplementasikan ilmu yang sudah dimiliki didunia kerja. Sebelum mengikuti PKL sekolah sudah membekali siswa dengan kemampuan dasar dalam kegiatan kerjanya. Dengan demikian siswa yang mengikuti praktek kerja Lapangan akan mudah beradaptasi dengan lingkungan kerja tempat dia ditempatkan. Namun pada kenyataannya harapan tersebut tidak dapat terpenuhi. Banyak kasus penyaluran siswa prakerin yang tidak sesuai dengan yang diharapkan baik oleh sekolah maupun oleh siswa. Selain itu pemantauan serta pendaftaran manual yang dilakukan oleh guru pembimbing terlihat cukup sulit, mengingat tempat pelaksanaan dan waktu yang dibutuhkan untuk memonitoring masing - masing siswa yang mengikuti prakerin jaraknya cukup jauh dan membutuhkan biaya akomodasi yang cukup tinggi. Dengan adanya permasalahan tersebut, sistem yang dibuat dengan menggunakan metode RAD (Rapid Development Application) mampu mengatasi permasalahan tersebut. Dengan melihat hasil uji coba menggunakan pengukuran SUS (System Usability Scale), Sehingga tujuan dan harapan dari pelaksanaan kegiatan tersebut dapat tercapai serta peningkatan kualitas pelaksanaan kegiatan siswa prakerin sesuai dengan keilmuan yang sudah didapatkan.
\end{abstract}

Kata Kunci : e-goverment, , RAD, USU, Sistem Informasi

\section{PENDAHULUAN}

Pendidikan merupakan aspek penting yang menjadi kebutuhan utama setiap manusia. Dengan pendidikan dapat tercipta perubahan sikap yang baik pada diri seseorang. Hal ini memberikan makna bahwa dengan pendidikan akan terwujud manusia yang berbudi luhur dan bermartabat, sesuai dengan amanat UUD 1945 dan UU Sisdiknas yang telah dipaparkan [1]. Praktek Kerja Lapangan (PKL) diberikan untuk siswa sekolah menengah kejuruan yang sudah memasuki kelas 2 atau kelas XI SMK. Tujuan prakerin adalah untuk memberikan kemampuan dan pengalaman bagi siswa untuk mengimplementasikan ilmu yang sudah dimiliki didunia kerja.

Sebelum mengikuti praktek kerja industri sekolah sudah membekali siswa dengan kemampuan dasar dalam kegiatan kerjanya. Dengan demikian siswa yang mengikuti praktek kerja industri akan mudah beradaptasi dengan lingkungan kerja tempat dia ditempatkan [2].

Landasan hukum pelaksanaan praktek kerja industri adalah undang-undang no. 20 tahun 2003 tentang sistem pendidikan nasional. Yang mana undang-undang tersebut mewajibkan sekolah atau tempat belajar untuk mempersiapkan para siswanya untuk siap ditempatkan dimana saja sesuai kebutuhan lingkunganya [3].

Namun pada kenyataannya harapan tersebut tidak dapat terpenuhi. Banyak kasus penyaluran siswa prakerin yang tidak sesuai dengan yang diharapkan baik oleh sekolah maupun oleh siswa. Terbukti dengan ditemukanya kegiatan yang tidak sesuai dengan implementasi keilmuan yang didapatkan selama di
SMK, dan bahkan malah banyak kegiatan yang menyimpang cukup jauh. Sehingga tujuan pelaksanaan prakerin tidak terpenuhi, selain itu pemantauan serta pendaftaran manual yang dilakukan oleh guru pembimbing terlihat cukup sulit, mengingat tempat pelaksanaan dan waktu yang dibutuhkan untuk memonitoring masing - masing siswa yang mengikuti prakerin jaraknya cukup jauh dan membutuhkan biaya akomodasi yang cukup tinggi.

Dengan adanya permasalahan tersebut, harapan kedepannya yaitu sebuah sistem yang dibuat agar mampu mengatasi permasalahan tersebut. Sehingga tujuan dan harapan dari pelaksanaan kegiatan praktek kerja lapangan dapat tercapai. Bukan hanya itu harapan dari adanya sistem ini, kerja sama antar pihak SMK dengan pihak DU/DI dapat terjalin dengan erat, serta peningkatan kualitas pelaksanaan kegiatan siswa prakerin sesuai dengan keilmuan yang sudah didapatkan dan pihak DU/DI mampu menyaring sumber daya baru yang lebih berkualitas.

\section{METODELOGI PENELITIAN}

\subsection{Sistem Manajemen}

Sistem Manajemen merupakan suatu proses serta prosedur yang biasa digunakan untuk memastikan apakah organisasi atau perusahaan bisa memenuhi standar pencapaian organisasi serta mampu menjalankan tujuan dari suatu organisasi. Salah satu tujuan organisasi atau perusahaan yaitu dapat memenuhi kualitas pelanggan ataupun suatu peraturan dalam mencapai tujuan maupun tanggung jawab terhadap aspek lingkungan. 
Dalam studi kasus ini manajemen merupakan sutu proses pengorganisasian serta pengkoordinasian suatu sumberdaya untuk mencapai sasaran tertentu. Sumberdaya tersebut mencakup objek yang berada pada satuan kegiatan dalam praktek kerja industri. Antara lain pembimbing sekolah, pembimbing perusahaan, dan siswa PKL. Efektifitas dapat dicapai ketika manajemen dalam perancanaan bisa dilakukan. Efisiensi dapat terjadi ketika tugas yang dilakukan dalam pendistribusian siswa PKL bisa dilaksanakan secara terorganisir dan benar.

\subsection{Praktek Kerja Lapangan (PKL)}

Kegiatan wajib dalam satuan pendidikan yang di ikuti oleh siswa siswi SMK adalah pembelajaran dan pelatihan yang dilaksanakan di dunia kerja atau dunia industri yang dikenal dengan DU/DI. Upaya dalam peningkatan mutu siswa dengan kompetensi yang sesuai dengan bidangnya akan dapat menambah bekal di masa datang untuk memasuki dunia kerja yang cukup ketat. Praktek kerja lapangan atau PKL memiliki tujuan sebagai wadah dalam meningkatkan kualitas siswa SMK sesuai dengan jurusannya. Kegiatan ini nantinya akan memantapkan pengalaman kerja sebelum memasuki dunia kerja yang sesungguhnya.

Adapun tujuan dari praktek kerja lapangan adalah sebagai berikut :

- Dapat membentuk pola pikir siswa PKL

- Menerapkan materi pelajaran yang sudah didapatkan di sekolah.

- Melatih siswa dalam berinteraksi serta berkomunikasi secara baik dan profesional di dunia kerja yang sebenarnya.

- Mempelajari ketrampilan yang dimiliki siswa supaya dapat di implementasikan dan dikembangkan dalam keseharian.

- Mengembangkan ilmu dasar yang dimiliki siswa PKL sesuai dengan bidangnya.

- Menanamkan dan membentuk semangat kerja bagi siswa Praktek kerja lapangan.

Praktek kerja lapangan merupakan memiliki manfaat yang sangat baik bagi perkembangan sumberdaya manusi di Indonesia. Salah satunya adalah sebagai berikut :

- Dapat meningkatkan efisiensi proses pendidikan serta menjadi tempat pelatihan yang berkualitas bagi calon tenaga kerja.

- Menghasilkan calon tenaga kerja yang memiliki ketrampilan, pengetahuan, dan semangat kerja yang sesuai dengan tuntutan di dunia industri.

- Menjalin hubungan erat antara sekolah dengan dunia usaha maupun dunia industri.
- Sebagai suatu sarana dalam menyiapkan SDM berkualitas yang sesuai dengan perkembangan teknologi informasi.

\subsection{Rapid Application Development (RAD)}

Penelitian sebelumnya yang tentang sistem informasi yang dibangun dapat menghasilkan laporan penilaian dari instansi tujuan dan menjadi indikator untuk memonitor ketercapaian pelaksanaan praktek kerja lapangan yang dilakukan. Sedangkan pengukuranya digunakan key performance indicator [4]. Berdasarkan penelitian selanjutnya sistem yang dibangun sudah dapat memonitor lokasi siswa dalam menginputkan data dengan cara validasi oleh penyelia yang ada di tempat PKL. Dalam hal metode pembuatan sistemnya menggunakan metode SDLC [5].

Dalam penelitian berikutnya, sistem yang dibuat dibangun dengan menggunakan bahasa pemrograman Visual Basic.Net. dan tidak menggunakan jaringan internet sehingga pengajuan hanya bisa dilakukan dikomputer sekolah saja dan yang dapat menggunakan aplikasi hanya bagian hubungan industri. System ini menggunakan metode waterfall pada saat pembangunanya [6].

Pada penelitian sebelumnya juga telah dilakukan perancangan mengenai kebutuhan akan system monitoring untuk bagian instansi perusahaan dan juga sekolah. Pihak ketiga yang digambarkan tersebut melakukan monitoring bukan hanya dari segi siswa, namun juga monitoring yang dilakukan oleh kedua belah pihak, yaitu sekolah dan juga instansi perusahaan [7].

Dalam penelitian ini penulis akan menggunakan metode Rapid application development (RAD). Dengan metode RAD sistem dikerjakan dalam waktu yang singkat, metode ini dapat bekerja dengan baik sesuai dengan rencana kerja jika projek yang dibuat dapat dibuat dalam modul-modul yang dikerjakan oleh sebuah tim tersendiri. Penggunaan metode ini efektif digunakan oleh perusahaan atau software house yang memiliki beberapa tim yang dapat bekerja bersamasama. Namun diakhir proses pengembangan tiap langkah harus dilakukan sinkronisasi agar semua proses yang dikerjakan dapat bekerja dengan baik. Pengerjaan sebuah projek dengan metode RAD dikerjakan antara 30-90 hari kerja dengan beberapa tim yang bekerja bersama- sama. Dalam rad ada 3 tahapan pengembangan 1. Rencana kebutuhan sistem. 2. Desain sistem 3. Implementasi [8].

Dalam tahap pertama client dan analis melakukan pertemuan untuk menyatukan persepsi apa sistem yang dibutuhkan oleh client sehingga tujuan sistem dibuat sesuai dengan kesiapan dan kebutuhan user. Dalam tahap kedua keterlibatan client sangat penting ketika sistem yang sudah dibuat disodorkan 
ke client dan analis, tugas client dan analis adalah harus segera mengoperasikan jika masih dirasa ada yang perlu diperbaiki client harus segera memberitahukan kepada programmer untuk memperbaiki. Dan jika sudah sesuai dengan kebutuhan maka proses selanjutnya dapat dikerjakan. Dalam tahap ketiga ini client dan analis dapat melakukan ujicoba sistem yang sudah dibuat dan dijalankan sesuai keadaan sebenarnya pada masa inipun masukan dari client dan analis masih dibutuhkan. Jika client dan analis sudah menyetujui maka sistem dapat digunakan secara luas.

Penggunaan metode RAD bukan hanya untuk mempercepat proses pembuatan aplikasi tetapi juga dapat meminimalisir kekurangan fitur yang diinginkan oleh client [9]. Karena selama pengerjaan client akan dapat mengetahui kekurangan atau proses pembuatan aplikasi sampai dimana. Sehingga ketika programmer selesai mengerjakan satu tahap dan telah diintegrasikan kemudian client dapat secara langsung mencoba dan memberi masukan kepada programmer jika ada kekurangan fitur yang diinginkan.

Dalam proses analisis peneliti berkonsultasi dengan pihak sekolah dan prerusahaan terkait dengan kebutuhan pada aplikasi yang akan dibuat. Selama proses analisis pihak sekolah dan perusahaan memberikan masukan kepada penulis tentang fitur apa saja yang dibutuhkan dalam aplikasi yang dibuat.

Memasuki proses desain peneliti membuat desain user interface untuk user prakerin, user sekolah dan user perusahaan. Dalam proses desain setelah desain selesai peneliti memberikan quisioner kepada para user baik dari siswa, sekolah maupun perusahaan untuk memberikan masukan kepada pengembang secara dinamis.

Memasuki tahap akhir yaitu implementasi peneliti memberikan kesempatan kepada para user untuk mencoba aplikasi yang telah dibuat dan sebelum percobaan para user diberikan pemahaman fitur yang ada dalam system melalui pelatihan.

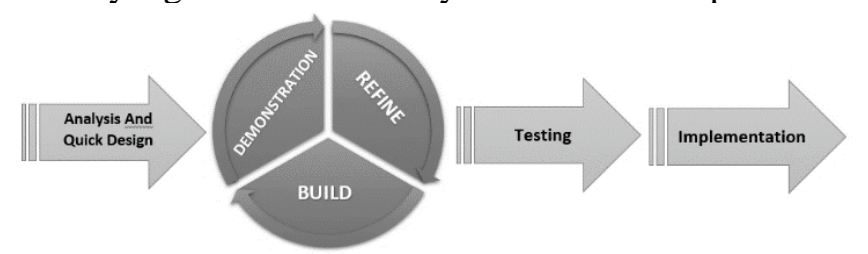

Gambar 1. Ilustrasi Model Rapid Development Application

Adapun Tahapan Rapid Application Development adalah sebagai berikut :

- Requirement Planning, Pada tahapan ini analist dan user melakukan identifikasi dan kebutuhan informasi dalam mencapai suatu tujuan. Hal tersebut merupakan suatu yang penting dengan adanya keterlibatan dari dua belah pihak. Di tahapan ini juga akan diketahui mengenai kebutuhan sistem dengan melakukan identifikasi kebutuhan informasi serta permasalahan yang dihadapi, sehingga tujuan dapat ditentukan dan kendala maupun permasalahan dapat di selesaikan. Analisis juga dapat digunakan untuk mengetahui aktivitas dan prilaku yang ada dalam sistem.

- Design Workshop, Pada proses ini keaktifan user sangat menentukan dalam mencapai sebuah tujuan. Perbaikan dan proses desain masih bias terdapat ketidak sesuaian antara analist dan user desain. Di tahapan ini user dapat memberikan komentar atas ketidak sesuaian desain serta perancangan system yang mengacu pada dokumentasi kebutuhan user yang telah dibuat di tahapan sebelumnya. Di tahapan ini keluaran yang diperoleh meliputi spesifikasi software serta system organisasi secara umum dan struktur data. Desain pemrograman dan proses bisnis yang didapatkan akan dimodelkan dalam arsitektur informasi. Untuk memodelkan system maka digunakan unifed modelling language (uml).

- Implentation, Pada tahapan ini programmer mengimplementasikan (coding) desain program yang disetujui analist dan user. Di tahap ini implementasi system siap dioperasikan oleh user. Proses pengujian pada program dilakukan sebelum system diaplikasikan pada organisasi. User nantinya akan memberikan tanggapan pada sistem yang sudah mendapatkan persetujuan.

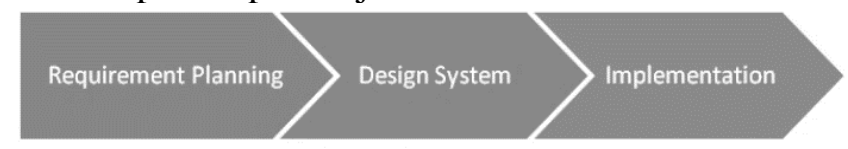

Gambar 2. Tahapan Pada Metode RAD

\subsection{Tehnik Pengumpulan Data}

Untuk mendapatkan data - data yang dibutuhkan dalam pembuatan system digunakanlah teknik pengumpulan data. Adapun teknik pengumpulan data yang digunakan adalah sebagai berikut :

a. Observasi

Observasi atau pengamatan adalah metode yang digunakan untuk pengumpulan data atau keterangan dengan cara mencatat fenomena yang terjadi serta mengamatinya [10]. Penelitian ini melakukan observasi terhadap sekolah dan perusahaan. Tujuan informasi ini adalah memperoleh informasi mengenai kegiatan distribusi praktek kerja lapangan. Pada penelitian ini dilakukan observasi pada sekolah menengah kejuruan yang berada dilingkungan dinas pendidikan kabupaten Banyuwangi serta beberapa instansi yang sudah melakukan kerja sama dengan sekolah yang menjadi objek observasi. 
Tujuan dari observasi ini adalah memperoleh informasi untuk dijadikan acuan informasi awal kebutuhan sistem. sehingga sistem yang dibuat tidak melenceng dari kebutuhan sekolah dan perusahaan yang ditempati.

b. Wawancara

Wawancara adalah salah satu teknik dalam pengumpulan data yang sering digunakan. Wawancara dilakukan dengan cara tanya jawab langsung antara penanya dan narasumber. dengan melakukan wawancara akan didapat data penunjang yang tidak ada dalam form atau berkas yang dimiliki.

Namun dalam metode ini kita harus tahu terlebih dahulu siapa narasumber yang tepat untuk menjawab pertanyaan yang akan kita ajukan. Jika narasumber yang kita tanya tidak kompeten dalam masalah yang kita ajukan, maka data yang didapat akan tidak valid sehingga menjadikan hasil penelitian yang tidak valid juga.

\section{c. Studi Pustaka}

Selain menggunakan observasi dan wawancara, studi pustaka juga sering digunakan dalam mendapatkan data dalam penelitian. Studi pustaka sendiri adalah kegiatan untuk mengumpulkan informasi yang sesuai dengan topik penelitian baik itu dari buku, internet, tesis, jurnal maupun disertasi yang sudah dipublikasikan. Semakin banyak referensi dari pustaka yang sudah terbit maka, akan didapatkan pembaruan yang diinginkan dan tidak tumpang tindih dengan tulisan yang lain.

\subsection{Sumber Data}

Setelah studi pustaka dan metodologi ditentukan maka selanjutnya dilakukan observasi serta analisa data. Tujuan dari tahap ini adalah untuk mendapatkan data secara kualitatif mengenai siapa saja yang nantinya akan menjadi target sebagai pengguna dalam sistem monitoring yang akan dibuat. Dalam data kualitatif tersebut telah digambarkan tujuan, motivasi dan informasi-informasi apa saja yang diperlukan oleh pengguna yang sebaiknya ada dalam aplikasi ini. Pada proses ini menghasilkan output berupa data kualitatif untuk pemodelan personal.

Adapun sumber data dari sekolah meliputi SMK 17 Agustus 1945 Muncar, SMK Muhammadiyah 6 Rogojampi, SMK PGRI Rogojampi, SMK PGRI 1 Giri Banyuwangi, dan SMKN Ihya'Ulummudin. Selain itu pihak dari perusahaan yang dijadikan tempat pengambilan data adalah Laboratorium STIKOM PGRI Banyuwangi.

a) Sumber Data Primer disini didapatkan dari informasi perorangan atau individu sebagai pihak pertama dan peniliti mendapatkannya secara langsung dari guru pembimbing serta prodi yang menyalurkan siswa PKL. Adapun dari pihak perusahaan adalah dari staf laboratorium yang mengontrol keseluruhan Laboratorium serta membimbing siswa PKL

b) Sumber Data Sekunder adalah data yang mendukung informasi data primer yang diperoleh dari internet, buku, dan dokumen lainnya yang masih berhubungan dengan kegiatan PKL.

\section{ANALISA DAN PEMBAHASAN}

3.1 Kebutuhan Fungsional

a) Kerja Sama Sekolah

Merupakan suatu kebutuhan dalam penyaluran siswa praktek kerja lapangan di perusahaan perusahaan tertentu. System kerjasama akan mempermudah distribusi siswa PKL ke perusahaan yang dituju. Selain itu privasi tempat praktek juga akan lebih terlindungi.

b) Pendaftaran Siswa PKL

Merupakan kebutuhan sekolah untuk mendaftarkan siswa prakerin, sehingga tidak lagi harus ke tempat perusahaan. Pihak sekolah bisa langsung membantu mendaftarkan siswanya secara langsung lewat system. Sehingga pihak perusahaan bisa melihat data identitas yang diajukan oleh sekolah untuk melakukan praktek kerja industri.

c) Pengelolaan Data Prakerin

Adalah kebutuhan sekolah dan perusahaan dalam mengelola informasi data PKL, supaya bisa digunakan untuk membuat cetak sertifikat secara online. Sehingga akan memudahkan bagi perusahaan, karena tidak lagi harus membuat sertifikat mulai awal serta data langsung terintegrasi dengan sertifikat secara system.

d) Pengelolaan Jadwal PKL

Merupakan kebutuhan dari perusahaan dimana penjadwalan dilakukan untuk melakukan pergantian sift atau tempat basecame siswa selama melaksanakan kegiatan PKL..

e) Pengelolaan Absensi

Merupakan kebutuhan dari perusahaan dan sekolah, dimana data absensi adalah bentuk dari kedisiplinan selama mengikuti PKL. Sehingga guru pembimbing akan lebih mudah dalam melakukan pemantauan siswanya.

f) Pengelolaan Nilai

Merupakan kebutuhan dari pihak perusahaan untuk menuliskan dan mencatat nilai. harapannya nilai akan terintegrasi kedalam cetak sertifikat. 


\subsection{Kebutuhan Antarmuka Sistem}

Dalam kebutuhan interface meliputi tampilan menu untuk hak akses sekolah, perusahaan, dan siswa praktek kerja industri. Selain itu juga pembentukan dari form inputan kegiatan siswa, informasi penjadwalan, dan absensi oleh perusahaan. Selain itu juga data sekolah yang melakukan kerja sama dengan perusahaan. Kemudahan dalam melakukan akses lewat hp ataupun dengan pc computer.

\subsection{Tahap Proses Desain}

a) Diagram UML.

Pada tahap ini didapatkan hasil dari pemetaan akan kebutuhan user, maka digunakanlah penggambaran secara terstructural. Skema dari system manajemen praktek kerja industri ini digambarkan secara keseluruhan. Secara garis besar dengan menggunakan diagram UML. Pada gambar dibawah ini menunjukkan usecase diagram secara keseluruhan dan garis besar pada tiga hak akses sekaligus.

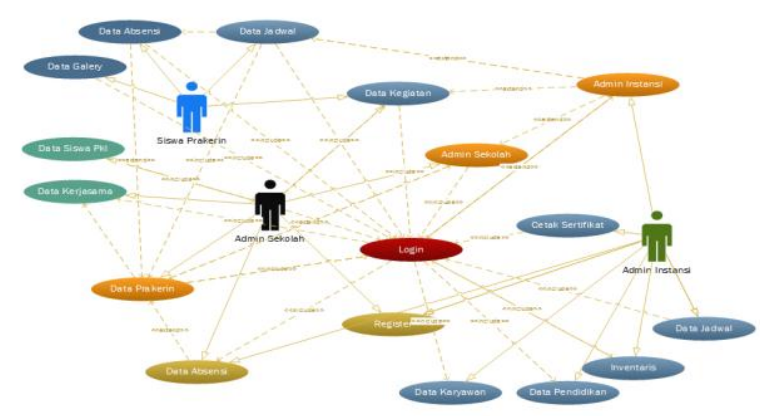

Gambar 3. Usecase Diagram Sistem

b) Desain Tampilan Halaman Perusahaan

Pada gambar di bawah ini menunjukkan keselurahan kebutuhan yang digunakan pada hak akses perusahaan. Adapun menu di perusahaan yang dibutuhkan salah satunya adalah kerjasama, data siswa PKL, penjadwalan, absensi dan penilaian.

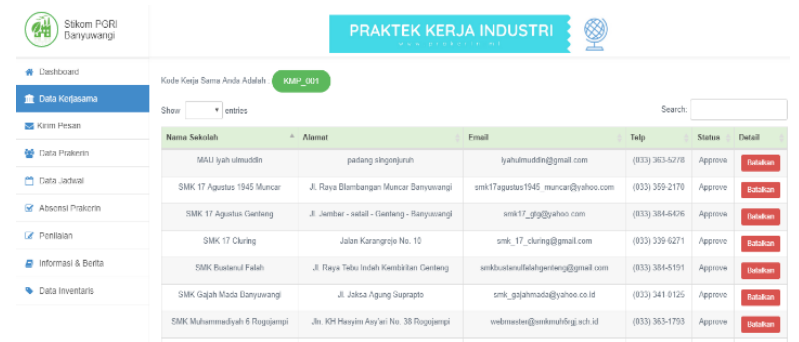

Gambar 4. Data kerja sama pada hak akses perusahaan.

c) Desain Tampilan Halaman Sekolah

Pada gambar di bawah ini menunjukkan hak akses dari pihak sekolah yang nantinya dikelola oleh guru pembimbing pada masing - masing sekolah. Pada hak akses sekolah ada beberapa menu yang sangat penting. Salah satunya adalah menu data siswa PKL yang didalamnya memberikan informasi mengenai kegiatan apa saja yang sudah dilakukan oleh siswa PKL. Serta kemudahan dalam melakukan pengajuan kerja sama dengan perusahaan yang di tuju.

Selain itu terdapat juga menu tentang galeri dan absensi. Dimana menu galeri adalah dokumentasi yang sudah dilakukan oleh siswa praktek kerja industri dan menu absensi digunakan untuk memonitoring seberapa banyak absensi alpa yang sudah dilakukan oleh siswa praktek kerja industri.

Dan hal penting yang mendukung pada proses monitoring ini adalah tentang record data nilai yang dilakukan oleh pihak sekolah. Sehingga akan memudahkan pihak sekolah untuk membantu melakukan penilaian serta cetak sertifikat secara otomatis.

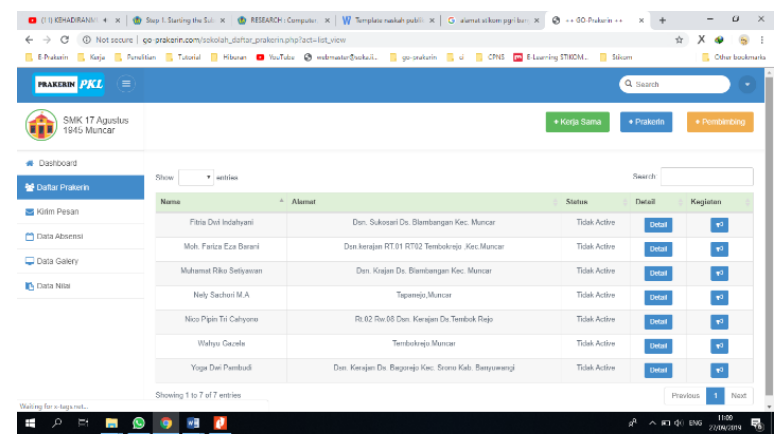

Gambar 5. Data siswa PKL pada hak akses sekolah.

d) Desain Tampilan Halaman PKL

Siswa PKL masing - masing mendapatkan akun untuk bisa mengakses di halaman hak akses. Adapun menu di halaman akses siswa praktek kerja industry ini adalah jadwal, identitas diri, data kegiatan serta gallery. Data kegiatan dari siswa yang dilakukan selama melakukan praktek kerja lapangan akan diinputkan didalam system. Sehingga dari pihak pembimbing sekolah nantinya akan bisa memantau kegiatan siswanya selama mengikuti PKL.

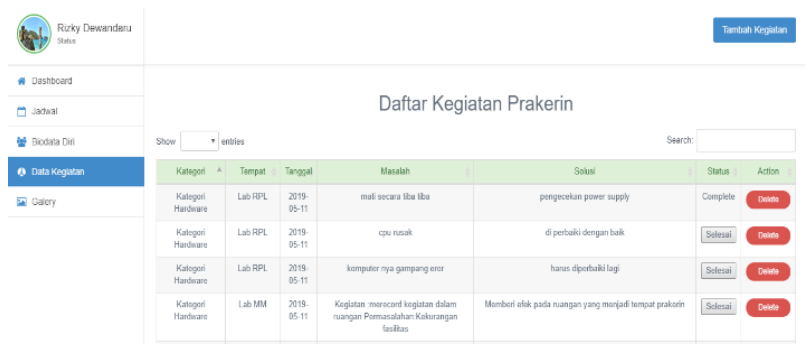

Gambar 6. Data kegiatan siswa pada hak akses siswa PKL 
Dengan terpenuhinya kebutuhan system secara fungsional maka perancangan system monitoring praktek kerja industri berbasis website dapat digunakan untuk memberikan informasi dalam memanajemen aktivitas siswa praktek kerja industry sesuai dengan tujuan awal dari penelitian.

peran praktek kerja industri berbasis website dapat digunakan untuk memberikan informasi dalam memanajemen aktivitas siswa praktek kerja industry sesuai dengan tujuan awal dari penelitian.

\section{PENGUJIAN DAN HASIL}

\subsection{Pengujian System Usability Scale (SUS)}

Tujuan dilakukannya uji coba ini adalah untuk mengetahui apakah hasil penelitian sudah sesuai dengan target yang sudah ditetapkan. pengujian sistem dilakukan dengan menggunakan skala SUS, dimana user tidak lagi mengetahui proses tapi melihat hasil dari proses saja.

Uji coba ini melibatkan siswa dari 4 sekolah SMK serta pembimbing dari masing-masing sekolah. 20 siswa dari smk pgri rogojampi, 20 siswa dari smk muhammadiyah 6 rogojampi, 20 siswa dari smkn ihya' ulumiddin, 17 siswa SMK 17 Agustus 1945 Muncar sehingga jumlah responden dari penelitian ini mencapai 77 responden.

uji coba dilakukan dengan cara admin memberikan akses kepada pembimbing pada tiap sekolah, kemudian pembimbing mendaftarkan siswa dari sekolahnya agar dapat mengakses aplikasi. Kemudian siswa yang sudah didaftarkan pada aplikasi dapat melakukan akses aplikasi yang sudah dihostingkan.

Adapun tahapan uji coba yang akan dilakukan dalam penelitian ini adalah dengan menggunakan cara SUS (System Usability Scale). SUS pada penelitian ini memiliki 10 pertanyaan dan 4 pilihan jawaban. Pilihan jawaban tersebut nantinya memiliki garis besar sangat setuju hingga kurang setuju. Di tahapan SUS ini memliki maksimal skor 100 dan minimal skor 0 [11]. Adapun table quisioner yang sudah di teliti dan diisi oleh siswa adalah sebagai berikut :

Tabel 1. Data pertanyaan untuk dilakukan perhitungan dengan SUS

\begin{tabular}{cl}
\hline No & \multicolumn{1}{c}{ Pertanyaan } \\
\hline 1 & $\begin{array}{l}\text { Aplikasi ini nantinya akan membantu anda } \\
\text { dalam proses pelaksanaan PKL. }\end{array}$ \\
\hline 2 & $\begin{array}{l}\text { Aplikasi ini menampilkan hasil sesuai dengan } \\
\text { kebutuhan. }\end{array}$ \\
\hline 3 & $\begin{array}{l}\text { Saya kurang memahami penggunaan tampilan } \\
\text { aplikasi dari go-prakerin. }\end{array}$ \\
\hline 4 & $\begin{array}{l}\text { Saya mersa fitur dashboard yang memberikan } \\
\text { informasi pada halaman utama sangat } \\
\text { membantu. }\end{array}$ \\
\hline
\end{tabular}

\begin{tabular}{cl}
\hline No & \multicolumn{1}{c}{ Pertanyaan } \\
\hline 5 & Aplikasi yang dijalankan sangat responsif. \\
\hline 6 & $\begin{array}{l}\text { Aplikasi yang digunakan tidak mudah untuk } \\
\text { dipahami. }\end{array}$ \\
\hline 7 & $\begin{array}{l}\text { Saya merasa penggunaan warna pada sistem } \\
\text { yang digunakan sangat konsisten. }\end{array}$ \\
\hline 8 & $\begin{array}{l}\text { Saya merasa menu yang disajikan sangat } \\
\text { mudah dimengerti. }\end{array}$ \\
\hline 9 & $\begin{array}{l}\text { Saya memahami betul input dari kegiatan } \\
\text { untuk sebagai monitoring guru pembimbing. }\end{array}$ \\
\hline 10 & $\begin{array}{l}\text { Keseluruhan dari system sangatlah bagus dan } \\
\text { mudah dipahami. }\end{array}$ \\
\hline
\end{tabular}

Seperti penjelasan SUS dengan pilihan 4 jawaban. Maka table jawabannya adalah sebagai berikut :

Tabel 2. Perhitungan skor dari pertanyaan yang diajukan.

\begin{tabular}{lcc}
\hline & Jawaban & Skor \\
\hline Sangat Setuju & 4 \\
\hline Setuju & 3 \\
\hline Cukup Setuju & 2 \\
\hline Tidak Setuju & 1 \\
\hline
\end{tabular}

\subsection{Perhitungan SUS}

Perhitungan SUS dilakukan saat data dari responden sudah dikumpulkan. Data tersebut nantinya akan dihitung dengan aturan menggunakan perhitungan skor SUS.

a) Data pilihan $\mathrm{A}$ akan memiliki skor 4

b) Data pilihan B akan memiliki skor 3

c) Data pilihan $\mathrm{C}$ akan memiliki skor 2

d) Data pilihan D akan memiliki skor 1

e) Dan skor sus didapat dari hasil penjumlahan skor setiap pertanyaan dan kemudian akan dikalikan 2.5.

Pada aturan selanjutnya skor untuk responden dijumlahkan dan dibagi dengan jumlah responden. Sehingga rumus dari SUS tersebut adalah sebagai berikut.

$$
\frac{\sum}{x}=\frac{\sum x}{n}
$$

$$
\begin{aligned}
& \dot{\bar{x}}=\text { skor rata }- \text { rata } \quad \sum x=\text { Jumlah Skor SUS } \\
& \mathrm{n}=\text { Jumlah Responden }
\end{aligned}
$$




\begin{tabular}{|c|c|c|c|c|c|c|c|c|c|c|c|c|}
\hline \multicolumn{11}{|c|}{ Skor Hasil Hitung SUS } & \multirow{2}{*}{ Jumlah } & \multirow{2}{*}{\begin{tabular}{|c|} 
Nilai \\
(Jumlah $\times 2.5$ ) \\
\end{tabular}} \\
\hline Respon & R1 & R2 & R3 & R4 & R5 & R6 & R7 & R8 & \begin{tabular}{l|l} 
R9 & F
\end{tabular} & R10 & & \\
\hline 1 & 3 & 2 & 4 & 4 & 3 & 2 & 4 & 3 & 2 & 4 & 31,0 & 77,5 \\
\hline 2 & 4 & 4 & 3 & 3 & 2 & 3 & 2 & 3 & 3 & 4 & 31,0 & 77,5 \\
\hline 3 & 3 & 2 & 4 & 4 & 3 & 2 & 4 & 3 & 2 & 4 & 31,0 & 77,5 \\
\hline 4 & 2 & 2 & 3 & 2 & 2 & 3 & 2 & 3 & 3 & 3 & 25,0 & 62,5 \\
\hline 5 & 3 & 2 & 4 & 4 & 3 & 2 & 4 & 3 & 2 & 4 & 31,0 & 77,5 \\
\hline 6 & 3 & 2 & 4 & 4 & 3 & 2 & 4 & 3 & 2 & 4 & 31,0 & 77,5 \\
\hline 7 & 3 & 2 & 4 & 4 & 3 & 2 & 4 & 3 & 2 & 4 & 31,0 & 77,5 \\
\hline 8 & 3 & 2 & 4 & 4 & 3 & 2 & 4 & 3 & 2 & 4 & 31,0 & 77,5 \\
\hline 9 & 2 & 2 & 1 & 4 & 2 & 2 & 3 & 3 & 3 & 3 & 25,0 & 62,5 \\
\hline 10 & 2 & 2 & 1 & 3 & 2 & 2 & 3 & 3 & 3 & 3 & 24,0 & 60,0 \\
\hline 11 & 2 & 2 & 1 & 3 & 2 & 2 & 3 & 3 & 3 & 3 & 24,0 & 60,0 \\
\hline 12 & 3 & 2 & 4 & 4 & 3 & 2 & 4 & 3 & 3 & 3 & 31,0 & 77,5 \\
\hline 13 & 3 & 2 & 4 & 4 & 3 & 2 & 4 & 3 & 3 & 3 & 31,0 & 77,5 \\
\hline 14 & 2 & 2 & 1 & 3 & 2 & 2 & 3 & 3 & 3 & 3 & 24,0 & 60,0 \\
\hline 15 & 3 & 2 & 4 & 4 & 3 & 2 & 4 & 3 & 2 & 4 & 31,0 & 77,5 \\
\hline 16 & 2 & 2 & 1 & 3 & 2 & 2 & 3 & 3 & 3 & 3 & 24,0 & 60,0 \\
\hline 17 & 2 & 2 & 3 & 3 & 2 & 3 & 3 & 3 & 3 & 3 & 27,0 & 67,5 \\
\hline 18 & 3 & 2 & 4 & 4 & 3 & 2 & 4 & 3 & 2 & 4 & 31,0 & 77,5 \\
\hline 19 & 2 & 2 & 3 & 3 & 2 & 3 & 3 & 2 & 2 & 3 & 25,0 & 62,5 \\
\hline 20 & 2 & 2 & 3 & 3 & 2 & 3 & 31 & $2 \mid$ & 2 & 3 & 25,0 & 62,5 \\
\hline \multicolumn{11}{|c|}{ Penilaian Rata - rata } & 28,2 & 70,5 \\
\hline
\end{tabular}

Gambar 7. Tabel hasil perhitungan dengan SUS

Dari salah satu table menunjukkan nilai usability sebanyak 70\%. Dan table secara keseluruhan adalah sebagai berikut:

Tabel 3. Hasil perhitungan dari 4 sekolah dengan Sistem Usability Scale

\begin{tabular}{clcc}
\hline No & \multicolumn{1}{c}{ Sekolah } & Responden & $\begin{array}{c}\text { Nilai } \\
\text { Usability }\end{array}$ \\
\hline 1 & $\begin{array}{l}\text { SMK PGRI } \\
\text { Rogojampi }\end{array}$ & 20 & $70,5 \%$ \\
\hline 2 & $\begin{array}{l}\text { SMK } \\
\text { Muhammadiyah 6 } \\
\text { Rogojampi }\end{array}$ & 20 & $77,1 \%$ \\
\hline 3 & $\begin{array}{l}\text { SMKN Ihya } \\
\text { ulumiddin }\end{array}$ & 20 & $75,3 \%$ \\
\hline 4 & $\begin{array}{l}\text { SMK 17 Agustus } \\
\text { 1945 Muncar }\end{array}$ & 17 & $73,5 \%$ \\
\hline \multicolumn{2}{c}{ Jumlah } & 77 & $74,1 \%$ \\
\hline
\end{tabular}

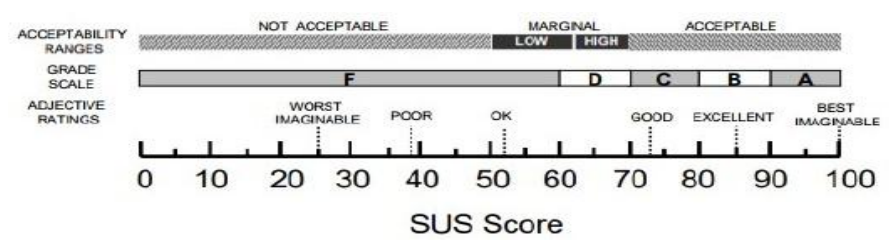

Gambar 8. Penentuan Hasil Penilaian [11].

Dari gambar diatas menunjukkan bahwa hasil dari penilaian mendapatkan skor $74 \%$. berdasarkan penilaian tersebut masuk kategori GOOD dengan grade scale C. berdasarkan usability penilaian tersebut bisa diterima dan layak.

\section{KESIMPULAN DAN SARAN}

Berdasarkan hasil dari penelitian mengenai monitoring siswa praktek kerja industry dengan metode RAD (Rapid Application Develompent) dan pengujian tingkat kepuasan penggunaan system menggunakan SUS ( System Usability Scale) maka didapatkan kesimpulan sebagai berikut:

a) Dengan menggunakan Metode RAD (Rapid Development Application) maka system monitoring siswa Praktek Kerja Industri dapat diselesaikan sesuai dengan kebutuhan bagi pihak sekolah maupaun dari pihak perusahaan.

b) Dengan Adanya system monitoring maka kegiatan siswa PKL mulai dari distribusi ke perusahaan hingga penilaian dari keseluruhan kegiatan siswa di lapangan, bisa diselesaikan dengan lebih mudah dan efisien.

c) Dengan tambahan bootsrap maka memberikan kemudahan siswa dalam mengakses halaman system lewat hp android.

d) Pengujian dengan SUS memberikan hasil penilaian yang lebih terstruktur dan terukur pada perangkat lunak. Dan dibuktikan dengan pengujian usability yang mendapatkan skor $74,1 \%$.

\section{Daftar Pustaka}

[1] A. M. Palerangi and F. R. Baharuddin, "Kontribusi pelaksanaan prakerin dan motivasi belajar terhadap hasil prakerin siswa smk," vol. 38 , no. 2 , pp. $167-$ $176,2015$.

D. Wardani, "KONTRIBUSI KETERAMPILAN SOSIAL DALAM PEMBELAJARAN IPS TERHADAP KESIAPAN KERJA PRAKTEK KERJA INDUSTRI (Studi Terhadap Peserta Didik Kelas XI SMKN Kota Bandung)," J. Penelit. Pendidik., vol. Edisi Khus, no. 2, pp. 154-163, 2011. I. P. Sari, Y. Yunus, and J. Santony, "Penempatan Lokasi Praktek Kerja Industri yang tepat dengan Metode Profile Matching," vol. 16, no. 1, pp. 51-56, 2018.

[4] P. W. Ningsih, T. Lusiani, and V. Nurcahyawati, "Rancang Bangun Sistem Informasi Praktek Kerja Industri Berbasis Web (Studi Kasus: SMK Al-Azhar Menganti Gresik)," J. Sist. Inf. Komput. Akunt., vol. 1, no. $1,2012$.

G. A. Susanto, E. Darmanto, and M. A. Arifin, "Sistem Monitoring Praktek Kerja Lapangan (Pkl) Pada Smk Assa'Idiyyah," Pros. SNATIF, pp. 255260, 2016.

[6] A. Rohman and Herlawati, "Sistem Informasi Praktek Kerja Industri Pada SMK Taruna Bangsa Bekasi," Bina Insa. Ict J., vol. 4, no. 2, pp. 197-208, 2017.

[7] A. H. Sumitro, "ANALISIS METODE TOGAF ARCHITECTURE DEVELOPMENT,” no. Selisik, pp. 1-7, 2018.

[8] T. Wahyuningrum and D. Januarita, "Perancangan 
Web e-Commerce dengan Metode Rapid Application Development ( RAD ) untuk Produk Unggulan Desa," vol. 2014, no. November, pp. 81-88, 2014.

[9] D. Metode, C. Dan, V. It, and Y. Hendrian, "Analisis Tata Kelola Dan Perencanaan Investasi Teknologi Informasi," J. Tek. Komput. AMIK BSI, vol. V, no. 1, pp. 105-112, 2019.

[10] S. Mania, "Observasi Sebagai Alat Evaluasi Dalam Dunia Pendidikan Dan Pengajaran," Lentera Pendidik. J. Ilmu Tarb. dan Kegur., vol. 11, no. 2, pp. 220-233, 2008.

[11] A. Bangor, T. Staff, P. Kortum, J. Miller, and T. Staff, "Determining what individual SUS scores mean: adding an adjective rating scale," vol. 4, no. 3, pp. 114-123, 2009. 